\title{
Language, gender and orientalist rhetoric in American fiction and travel writing on the US conquest and colonization of the Philippines (1898-1929)
}

\author{
Tom Sykes, University of Portsmouth
}

The Philippine-American War (1899-1902) was arguably the foundational event in US imperialism, bearing chilling parallels with later US campaigns in Vietnam and Iraq. This article discusses American popular novels of the period by Edward Stratemeyer, Archibald Clavering Gunter, Charles King and others that, guided by a number of imperialist, colonialist and social Darwinist assumptions, textually produce the war in ways that omit, distort or excuse the conduct of the US military and colonial order. Inspired by researches into orientalist and other rhetorics, the article examines the mobilization of linguistic devices and narrative strategies. Finally, the article considers how, after the US had consolidated its control over the Philippines, travel writers such as William D. Boyce applied similar rhetorical techniques to discursively negotiate the contradictions of the new American colonial ideology of "benevolent assimilation", which depended somewhat uneasily on tropes of modernization, partnership and submissive feminization.

KEYWORDS: $\underline{\text { Asian studies, }}$ travel writing, orientalism, American literature, $\underline{\text { Philippines, }}$ PhilippineAmerican War

"The 1899 Philippine-American War is not the sort of topic the Filipino public likes to talk about", writes the Filipino historiographer Reynaldo C. Ileto (2002lleto, Reynaldo C. 2002. "The Philippine-American War: Friendship and

Forgetting." In Vestiges of War: The Philippine-American War and the Aftermath of an Imperial Dream 1899-1999, edited by Angel VelascoShaw and Luis H Francia, 3-21. New York: New York University Press. [Google Scholar]). There is an equivalent absence of the event from American political, media and literary discourses and it remains to this day "The war we forget" (Rockoff 2012Rockoff, Hugh. 2012. America's Economic Way of War: War and the US Economy from the Spanish-American War to the Persian Gulf War. New York: Cambridge University Press.[Crossref], [Google Scholar], 83). One reason for this is that "to imagine Filipinos warring with Americans simply contradicts the dominant tropes of the Philippine-American relationship [ ... ] expressed in kinship terms" (Ileto 2002lleto, Reynaldo C. 2002. "The Philippine-American War: Friendship and Forgetting." In Vestiges of War: The Philippine-American War and the Aftermath of an Imperial Dream 1899-1999, edited by Angel VelascoShaw and Luis 
H Francia, 3-21. New York: New York University Press. [Google Scholar], 3). When justifying foreign military adventurism over the last century, US elites have preferred the fustian of "kinship", "aid" and "humanitarian intervention" (Scheffer 1992Scheffer, David J. 1992. "Towards a Modern Doctrine of Humanitarian Intervention." University of Toledo Law Review 23: 253274. [Google Scholar], 253-274) to idioms such as "imperialism", "colonialism" or "conquest". Arguably, this inclination has been informed by two slightly differing hegemonic perceptions about the US's role in world affairs: first, its reticence to self-identify as an empire at all - as scholars on both the political left and right have contended (Monbiot 2004Monbiot, George. 2004. "Empire of Denial." The

Guardian, June 1.https://www.theguardian.com/world/2004/jun/01/usa.comme nt [Google Scholar], 1; Ferguson 2009Ferguson, Niall. 2009. Colossus: The Rise and Fall of the American Empire. London: Penguin. [Google Scholar]) and second, its view of itself as an "international policeman"

(Peace 2010Peace, Roger. 2010. "Cultivating Critical Thinking: Five Methods for Teaching the History of U.S. Foreign Policy." The History Teacher 43: 265273. [Google Scholar], 266) whose occupations of foreign territory are necessary to confront tyranny and promote democracy, human rights and prosperity. From the conquest of the Philippines to the present day, both perceptions have been undergirded by conscious efforts on the part of politicians and policymakers to distance American conduct abroad from the violence, racism, autocracy, acculturation and exploitation associated with the older European empires that directly ruled large swathes of the globe from the 18th century until the middle of the 20th. In 1898, shortly after the US formally took possession of the Philippines, President William McKinley wrote: "we come, not as invaders or conquerors, but as friends"

(McKinley 2011McKinley, William. 2011. "William McKinley: Benevolent Assimilation." Letter, December 21st 1898." In The Encyclopedia of the Spanish-American and Philippine-American Wars Vol. 1, edited by Spencer C Tucker, 924. Santa Barbara, CA: ABC Clio. [Google Scholar], 924). Earlier that year, he had explicitly criticized Spanish colonialism in Cuba and its "cruel, barbarous and uncivilized practices" towards "a dependent people striving to be free" (McKinley 1898McKinley, William. 1898. "War Message." In Papers Relating to Foreign Affairs, editor unnamed, 750-760. Washington, DC: US Department of State. [Google Scholar], 750), while claiming that America's mission was "to put an end to the barbarities, bloodshed, starvation, and horrible miseries now existing there" (758). Furthermore, said McKinley, "I speak not of forcible annexation, for that cannot be thought of. That, by our code of morality, would be criminal aggression" (757). Whenever American presidents since McKinley have ordered military assaults on smaller colonial or postcolonial nations, they have explicitly denied imperialist objectives and invoked McKinley's argot of security, protection and justice. After sending marines to the Isthmus of Panama in late 1903, President Theodore Roosevelt (1904Roosevelt, Theodore. 1904. "Special Message, January 4." In The American Presidency Project, edited by GerhardPeters and John 
T Woolley,http://www.presidency.ucsb.edu/ws/?pid=69417 [Google Scholar]) said "the United States should control, police, and protect the [Panama] canal" and assume "the position of guarantor of the canal and of its peaceful use by all the world" (para. 7). In 1965, at the height of European decolonization in Africa and Asia, President Johnson (1965Johnson, Lyndon. 1965. "Why We Are in Vietnam." In Modern America: A Documentary History of the Nation since 1945, edited by Gary Donaldson, 117-120. New York: Routledge. [Google Scholar]) said of American entanglement in Indochina: "we want nothing for ourselves, only that the people of South Vietnam be allowed to guide their own country in their own way" (118). By time of the postcolonial moment of the early 21 st century, when Europeanstyle settler colonialism and military imperialism were widely seen as monstrous and anachronistic, George W. Bush (2003Bush, George. 2003. We Will Prevail: President George W. Bush on War, Terrorism and Freedom. New York: Continuum. [Google Scholar]) said in the prelude to the US-led invasion of Iraq: "If we must begin a military campaign, it will be directed against the lawless men who rule your country and not against you. As our coalition takes away their power, we will deliver the food and medicine you need" (233). After the NATO (North Atlantic Treaty Organization) bombing of Libya, Barack Obama (2011Obama, Barack. 2011. "Remarks by the President in Address to the Nation on Libya."https://obamawhitehouse.archives.gov/the-pressoffice/2011/03/28/remarks-president-address-nation-libya [Google Scholar]) announced: "Confronted by [Qadaffi's] brutal repression [ ... we ] had a unique ability to stop that violence: an international mandate for action [based on ... ] a plea for help from the Libyan people themselves" (n.p.).

As Bush and Obama were to do later in different contexts, McKinley had framed the US attack on the Philippines as a rescue operation to save innocents from the clutches of dictatorship. However, as with Iraq and Libya, the real-life outcomes of the campaign were far from humanitarian. After the US declared war on the Spanish Empire in April 1898, it informally assured Filipino nationalist rebels led by Emilio Aguinaldo that, if they allied with the Americans to overthrow the Spanish colonial regime in the Philippines, the rebels would be free to found an independent republic (Constantino 2010Constantino, Renato. 2010. A History of the Philippines: From Spanish Colonization to the Second World War. New York: Monthly Review Press. [Google Scholar], 212). As soon as the Spanish had been defeated, the Americans reneged on this offer, a decision which resulted in a confrontation with Aguinaldo's forces that began in February 1899. One-sixth of the population (200-250,000 people) was killed in the conflict, due to - as was to be the case in the Vietnam War - the US army's reluctance to distinguish between civilians and combatants (villages were routinely torched and some officers ordered their men to slaughter all males and females older than ten years of age), and its tactic of "strategic hamleting" that caused largescale starvation and disease (Zinn 2001Zinn, Howard. 2001. A People's History of the United States: 1492-Present. New York: Harper Collins. 
Amazon Kindle e-book. [Google Scholar], loc. 5923). Dylan Rodriguez (2010Rodriguez, Dylan. 2010. Suspended Apocalypse: White Supremacy, Genocide, and the Filipino Condition. Minneapolis, MN: University of Minnesota Press. [Google Scholar]) designates the US operation a "genocide" stimulated by the same devotion to "white supremacy" that signalized the massacres of Native Americans in the late 19th century (98-99).

With some salutary exceptions, US popular novels, memoirs and travelogues of the period omit, downplay or distort the details of US misconduct in the war and offer "obfuscatory justifications" (Ashcroft, Griffiths, and

Tiffin 1998Ashcroft, Bill, Gareth Griffiths, and Helen Tiffin. 1998. Key Concepts in Post-Colonial Studies. London: Routledge. [Google Scholar], 47) for it. Inspired by critical linguists such as Norman Fairclough (2013Fairclough, Norman. 2013. Language and Power. Oxford: Routledge. [Google Scholar]) and researches into orientalist rhetoric by Edward Said

(1985Said, Edward. 1985. Orientalism. London: Peregrine. [Google Scholar]), Vernadette Vicuña Gonzalez (2013Gonzalez, Vernadette Vicuña. 2013. Securing Paradise: Tourism and Militarism in Hawai'i and the Philippines. Durham, NC: Duke University Press.[Crossref], [Google Scholar]), Neferti Xina M. Tadiar (2004Tadiar, Neferti, and M. Xina. 2004. FantasyProduction: Sexual Economies and Other Philippine Consequences for the New World Order. Hong Kong: Hong Kong University Press. [Google Scholar]) and David Spurr (1993Spurr, David. 1993. Rhetoric of Empire: Colonial Discourse in Journalism, Travel Writing and Imperial Administration. Durham, NC: Duke University Press. [Google Scholar]), I examine these American texts' mobilization of linguistic devices such as Edward Stratemeyer's (1898Stratemeyer, Edward. 1898. Under Dewey at Manila or the War Fortunes of a Castaway. Boston, MA: Lee and Shepard. [Google Scholar], 1900Stratemeyer, Edward. 1900. The Campaign of the Jungle or under Lawton through Luzon. Boston, MA: Lee and Shepard. [Google Scholar], 1902Stratemeyer, Edward. 1902. Under MacArthur in Luzon or Last Battles in the Philippines. Boston, MA: Lee and Shepard. [Google Scholar]) application of "modalizing" grammatical forms in order to persuade his young male readership of the historical verisimilitude of his highly partisan martial adventure novels, and narrative strategies including the conscious "excision" and "reduction" of morally and politically uncomfortable aspects of the conflict (Said 1985Said, Edward. 1985. Orientalism. London: Peregrine. [Google Scholar], 167). Influenced as I am by the methodology and theoretical framework of Edward Said's (1985Said, Edward. 1985. Orientalism. London: Peregrine. [Google Scholar]) classic study Orientalism, which, as Said admits, engages with a "broadly construed 'field' " of "theories, epics, novels, social descriptions, and political accounts" (3-4), my focus is somewhat narrower: on the popular literary genres of the novel and the travelogue. According to Morton J. Netzorg (1990Netzorg, Walton J. 1990. "The Philippines in Mass-Market Novels." 
In Asia in Western Fiction, edited by Robin W Winks and James R Rush, 175195. Manchester: Manchester University Press. [Google Scholar]), colonial novels of that period "appealed to a mass audience" and had "some chance of shaping American public ideas or impressions about the Philippines" (175). In addition to prose fiction, western travelogues about Asia, Africa and Latin America have, so Patrick Holland and Graham Huggan (2000) aver, textually produced the non-European world according to western fixations: the Congo was for Joseph Conrad "a mirror to the dark side of the soul" (69) and the Amazon was regarded as a "happy hunting ground" by plucky adventurers (77). In the specific case of the Philippines, Vernadette Vicuña Gonzalez has posited a dominant male/submissive female power binary as a vital coordinate of the textual space conjured by American writers of the colonial and neocolonial periods. Her thesis is especially relevant to the American policy regarded by President McKinley as "benevolent assimilation" (McKinley 2011McKinley, William. 2011. "William McKinley: Benevolent Assimilation." Letter, December 21st 1898." In The Encyclopedia of the Spanish-American and Philippine-American Wars Vol. 1, edited by Spencer C Tucker, 924. Santa Barbara, CA: ABC Clio. [Google Scholar], 924), which aimed to legitimize US colonial projects in the Philippines with the language of fraternity, guidance and mutual respect.

\section{Modality and faux objectivity}

Said and other postcolonial theorists have sought to deconstruct "statements that can be made about the world that involve certain assumptions [.. and] become protected by the assertion of 'truth' " (Ashcroft, Griffiths, and Tiffin 1998Ashcroft, Bill, Gareth Griffiths, and Helen Tiffin. 1998. Key Concepts in Post-Colonial Studies. London: Routledge. [Google Scholar], 34). In the Philippine-American War context, numerous American writers attempt to reinforce the normativity of their propositions with a technique that the sociolinguist Norman Fairclough (2013Fairclough, Norman. 2013. Language and Power. Oxford: Routledge. [Google Scholar]) terms "expressive modality": word choices and grammatical forms that reveal a "speaker or writer's authority with respect to the truth or probability of a representation of reality" (105). Edward Stratemeyer's (1898-1901) "Old Glory" series of "boy's own" adventure novels features pompous introductions that make obdurate claims regarding historical credibility. In The Campaign of the Jungle, or Under Lawton Through Luzon (Stratemeyer 1900Stratemeyer, Edward. 1900. The Campaign of the Jungle or under Lawton through Luzon. Boston, MA: Lee and Shepard. [Google Scholar]), the fourth book in the sequence that follows the fortunes of two soldier brothers serving under General Lawton, Stratemeyer asserts that the story is based on real-life military reports and personnel testimonies: "The author has endeavoured to be as accurate historically, as possible" (iv). In that quotation, the simple present-tense verbs "has" and "are" have the modalizing effect of reassuring the reader of Stratemeyer's sincerity 
about the truth status of his story, for such words, according to Fairclough (2013Fairclough, Norman. 2013. Language and

Power. Oxford: Routledge. [Google Scholar]), are the "conventions routinely drawn upon in discourse to embody ideological assumptions which come to be taken as mere 'common sense', and which contribute to sustaining existing power relations" (64). Another pot-boiler, Under Dewey at Manila, or the War Fortunes of a Castaway (Stratemeyer 1898Stratemeyer, Edward. 1898. Under Dewey at Manila or the War Fortunes of a Castaway. Boston, MA: Lee and Shepard. [Google Scholar]), which fictionalizes the Battle of Manila Bay when the advanced, steam-powered US Asiatic Squadron destroyed the Spanish fleet stationed in the Philippines, begins with the pledge that it will "trace, incident by incident, just as they actually happened" (iii). The intensifier "actually" appears to endorse the authenticity of both Stratemeyer's statement and the source material it is based on. Leaving aside these subtle modalities, the reader begins to doubt Stratemeyer's earlier promise of impartiality when he descends into one-sided patriotism: "the complete defeat upon one side was entirely outbalanced by almost total exemption from harm by the other" (iii). It is certainly verifiable from the historical evidence that the US routed the Spanish in that skirmish, but the triumphalist adjectives and adverbs ("complete", "entirely" and "total") through which Stratemeyer conveys this fact betray his personal slant. In another ruse to wrap authorial opinion in the cloak of objective truth, Under Dewey at Manila's expositional narration, which conveys the thoughts and conversations of the novel's characters, is frequently interrupted by an omniscient voice that makes evaluative judgements replete with approving adjectives about the events recounted: "the wonderful engagement of which I am about to relate" (Stratemeyer 1898Stratemeyer, Edward. 1898. Under Dewey at Manila or the War Fortunes of a Castaway. Boston, MA: Lee and Shepard. [Google Scholar], 194; my emphasis). The device has become even more intrusive by the concluding chapters of the novel: "That Larry was proud at having participated in the glorious conquest was but natural. What American boy would not have been proud?" (281).

The anthropologist Neferti Xina M. Tadiar's research into the function of dream, desire and the social imagination in unequal Philippine-American political and economic interactions since 1898 provides a possible answer to why novels such as Stratemeyer's employ expressive modality. Stratemeyer's convictions about the best possible intentions of the US invasion (its "wonderful" and "proud" aims) underwrite what Tadiar would dub a "fantasyproduction" of the Philippines that is persuasive precisely because it relies on emotional and subjective categories such as "love", "pride" and "dignity" (Tadiar and Xina 2004Tadiar, Neferti, and M. Xina. 2004. Fantasy-Production: Sexual Economies and Other Philippine Consequences for the New World Order. Hong Kong: Hong Kong University Press. [Google Scholar], 32). For Tadiar, who is here inspired by Slavoj Žižek's theories of psychology and ideology, such categories cut deep into "the symbolically structured meaning 
(the unconscious) that shapes and regulates our desires" (9) and have become politically and socially influential in the Philippine context because "imagination [is ... ] a central force in the creation of social projects" and "is an intrinsic, constitutive part of political economy" (4).

\section{Excision and reduction}

If orientalist authors on the Philippines at this time select certain words and phrases over others to suit their ideological dispositions, they also omit certain words and phrases for the same objective. I have found it useful here to draw on Edward, Said's

(1985Said, Edward. 1985. Orientalism. London: Peregrine. [Google Scholar]) concepts of "excision" and "reduction" (167) of othered cultural phenomena. Said holds that the Victorian Egyptologist Edward William Lane (a contemporary of many of the authors examined in this article) was so anxious about the reaction his western readers would have to the radical otherness of Egyptian sexual mores that he consciously "excised from [the Orient] what, in addition to his own human sympathies, might have ruffled the European sensibility"

(Said 1985Said, Edward. 1985. Orientalism. London: Peregrine. [Google Scholar], 167). Another of Lane's signifying practices was to understate "[the Orient's] odd calendars, its exotic spatial configurations, its hopelessly strange languages, its seemingly perverse morality"; such "eccentricities of Oriental life" were "reduced considerably when they appeared as a series of detailed items presented in a normative European prose style" (167). According to Said, other orientalists have applied the reduction strategy to non-western political situations, as illustrated by the conservative historian Bernard Lewis's "condescension" towards development in the Arab world: "Revolution is excitement, sedition, setting up a petty sovereignty - nothing more; the best counsel (which presumably only a Western scholar and gentleman can give) is 'wait until the excitement dies down' "

(Said 1985Said, Edward. 1985. Orientalism. London: Peregrine. [Google Scholar], 315). Numerous British and American texts of the PhilippineAmerican War period deploy comparable editorial and representational mechanisms in their one-sided, pro-American version of events.

Thus The Campaign of the Jungle not only entirely excises American atrocities but frequently decries the abuses of the insurgents, including their "terrible cruelty" (Stratemeyer 1900Stratemeyer, Edward. 1900. The Campaign of the Jungle or under Lawton through Luzon. Boston, MA: Lee and Shepard. [Google Scholar], 51) to prisoners and their penchant for committing arson attacks that imperil innocent civilians (when, as the historical sources above insist, arson was in actuality a far more common US tactic). Stratemeyer's approach here resembles Freud's concept of "projection" in which "hostility [ ... ] is ejected from internal perception into the external world, and thus detached from them [the mental patient] and pushed on to someone 
else" (Freud 2001Freud, Sigmund. 2001. Totem and

Taboo. Oxford: Routledge. [Google Scholar], 27). In colonial literary discourse, projection serves as a tool for mystifying the west's fears and desires relating to its unequal and exploitative interactions with the non-western world.

Young's (1995Young, Robert J.C. 1995. Colonial Desire: Hybridity in Theory, Culture and Race. London: Routledge. [Google Scholar]) monograph Colonial Desire: Hybridity in Theory, Culture and Race contends that 19th-century English scientific and cultural texts imbued subaltern peoples and exotic, peripheral landscapes with white male fantasies of interracial sex, while Casey Blanton (2002Blanton, Casey. 2002. Travel Writing: The Self and the World. New York: Routledge. [Google Scholar]) argues that Graham Greene, in his 1935 travel narrative Journey Without Maps, superimposes his traumatic childhood memories onto "a peculiar, haunted Liberia, that may or may not bear any resemblance to the place itself" (62). The fact that domestic critics of the Philippine-American War (see the final section of this article for closer readings of these commentators) focused on the brutality of US troops in the Philippines may well have aroused in supporters of the conflict strong enough insecurities about such transgressions that they were all too keen to reimagine them as the responsibility of enemy combatants.

On the one occasion in the novel when Stratemeyer depicts a US soldier behaving in an unethical manner - he kidnaps a native woman and carries her on his back as a human shield before discarding her unceremoniously in a forest - the reader is invited to feel neither compassion for the woman nor disapproval of the soldier. Rather, it is a stroke of "good luck" that the woman happens to be a "close relative" of a rebel chief who will not fire on our escaping heroes lest he harm her

(Stratemeyer 1900Stratemeyer, Edward. 1900. The Campaign of the Jungle or under Lawton through Luzon. Boston, MA: Lee and Shepard. [Google Scholar], 51-52). Hence, in a bizarre process of moral alchemy, the entirely selfish and exploitative behaviour of the soldier that risks the life of an innocent bystander is converted into a feat of heroic ingenuity because the soldier has God and righteousness on his side and the Filipinos are uncivilized subhumans whose lives are significantly cheaper than those of the Americans.

Jack Curzon, by Archibald Clavering Gunter (1898Gunter, Archibald Clavering. 1898. Jack Curzon (Being a Portion of the Records of the Managing Clerk of Martin, Thompson \& Co., English Merchants Doing Business in Hong Kong, Manila, Cebu and the Straits

Settlements). Hurst: New York. [Google Scholar]), a novel published just before The Campaign of the Jungle and set during the earlier phase of the conquest when the US was fighting the Spanish, is replete with the kinds of reductions Said locates in Bernard Lewis and other reactionary scholars. In one scene, the méstiza (mixed race American and Filipina) character Maud Gordon provides an offhand critique of anti-colonial nationalism when, during chatter with some US Navy officers at a Manila club, she refers to the political 
situation in Cuba (which, like the Philippines, the US has attacked under the pretext of aiding rebel factions against the Spanish):

"Oh I believe there is a revolution or rebellion there or something of the kind,"replies the girl [Maud], and they all go into an Annapolis gossip as she tells them how Mrs. Rear-Admiral Dawson snubbed Mrs. Commodore Brown, and that Miss Sally Jenkins was the belle of the last graduation hop.

(Gunter 1898Gunter, Archibald Clavering. 1898. Jack Curzon (Being a Portion of the Records of the Managing Clerk of Martin, Thompson \& Co., English Merchants Doing Business in Hong Kong, Manila, Cebu and the Straits Settlements). Hurst: New York. [Google Scholar], 28)

Gunter relegates this seismic development in imperial geopolitics to an aside about local tittle-tattle. The US involvement is unmentioned, excised. While Maud's political naivety could be read as a sine qua non of her gender Gunter (1898Gunter, Archibald Clavering. 1898. Jack Curzon (Being a Portion of the Records of the Managing Clerk of Martin, Thompson \& Co., English Merchants Doing Business in Hong Kong, Manila, Cebu and the Straits Settlements). Hurst: New York. [Google Scholar]) was a conservative Victorian patriarch who, elsewhere in the book, makes a number of essentialist and misogynistic claims about women as "impulsive", "vindictive" and "fickle" (76-77) - his male characters, particularly those who ought to know something about international relations, are equally dismissive of or ignorant about the Cuban and Philippine struggles for self-determination. When the eponymous hero of the novel, the British shipping clerk Jack Curzon, first learns of the rebels' siege of Manila, he nonchalantly states: "Apparently something political and military is taking place even now" (67). Such reductions are in line with a trajectory of dominant American historiography that, according to Reynaldo C. Ileto (2017lleto, Reynaldo C. 2017. Knowledge and Pacification: On the U.S. Conquest and the Writing of Philippine History. Manila: Ateneo de Manila University Press. [Google Scholar]), has sought to vindicate 20th-century US interference in the Philippine polity by claiming that Filipinos have been - and will always be unfit to govern themselves due to a "cacique" (289) mentality of "repressive, manipulative" tyranny, election-rigging, graft, "clientilism" and clannish "factionalism" (267-287).

\section{Passive aggressions}

A further stylistic manoeuvre constitutive of these texts' selective purview is the application of the passive voice, a grammatical formulation that Fairclough (2013Fairclough, Norman. 2013. Language and

Power. Oxford: Routledge. [Google Scholar]) holds to be guided by "ideological choices to [ ... ] background agency" because "action[s]" are described without "responsible agents" or "attributed state[s]" (102). Although the passive voice was a more commonplace feature of literary style in 
Stratemeyer's time than it is today, partly because "19th-century writers on grammar and usage explained the structure and function of passives without any negative spin" (Pullum 2014Pullum, Geoffrey K. 2014. "Fear and Loathing of the English Passive." Language and Communication 37 (2): 1-6.

doi:10.1016/j.langcom.2013.08.009.[Crossref], [Google Scholar], 1), the mode seems to be applied more strategically in The Campaign of the Jungle to absolve the American troops of their active role in the Philippine aggression, a prime example being "A howl arose on the night air, and one gun went off" (Stratemeyer 1900Stratemeyer, Edward. 1900. The Campaign of the Jungle or under Lawton through Luzon. Boston, MA: Lee and Shepard. [Google Scholar], 51). The following construction, while not passive in the formally linguistic sense, does not so much excise the agents of the hostilities as suggest that no one side is guilty of them, which in turn implies moral equivalence between a powerful imperial belligerent and its benighted victims, who are acting out of self-defence: "At this time trouble began to break out between the United States and the insurgents who had been fighting the Spanish" (19). To return to Vietnam parallels, David Spurr (1993Spurr, David. 1993. Rhetoric of Empire: Colonial Discourse in Journalism, Travel Writing and Imperial Administration. Durham, NC: Duke University Press. [Google Scholar]) highlights a 1961 Newsweek article that utilizes "passive construction and a vocabulary which obscures the nature of concrete action" (38) to exculpate the active role of the US armed forces in that conflict. "The countryside", Spurr continues " 'has been pacified' and 'brought under control'. This leaves unnamed the agents and means of pacification and control" (38).

The diction of Stratemeyer's equivocating sentence above is also significant, for the word "trouble" is, in Fairclough's lexicon, a "euphemism" or "word which is substituted for a more conventional or familiar one as a way of avoiding negative values" (Fairclough 2013Fairclough, Norman. 2013. Language and Power. Oxford: Routledge. [Google Scholar], 98-99). Just as Fairclough refers to a 1980s essay about British psychiatric practices that carefully substitutes the word "seclusion" for "solitary confinement" as a strategy "of avoidance with respect to the expressive values of words for relational reasons", so Stratemeyer chooses the noun "trouble", perhaps since its "relational" synonyms (stress, difficulty, nuisance, pickle) are not as redolent of "negative values" - at least not for Stratemeyer's young, patriotic, late Victorian readership - as war, conflict or bloodshed, let alone massacre, extermination or genocide. We see here, then, that the (conscious or unconscious) enterprise of deceiving the American public about both the nature and cause-and-effect of the US invasion was as much a question of the minute detail of individual words and phrases as it was a matter of broader-scale expurgations or de-emphases regarding the battlefield behaviour, political beliefs and military agency of the insurrectionists. Such a circumspect approach to language and its potential meanings was to become 
critically important when the US won the war and began consolidating the peace.

\section{"The pious new name of the musket"}

In July 1902, with most of the rebel leaders dead or captured, the US passed the Philippine Organic Act, which established a bill of rights, an elected legislature and other liberal political apparatuses informed by the new colonial ideology of benevolent assimilation, whereby the US would rule the Philippines in a supposedly more enlightened, humane and egalitarian fashion than had Spain (McKinley quoted in Blount 1913, 149). McKinley had coined the term "benevolent assimilation" in 1899, holding that, once the US "military administration" had achieved hegemony over the islands, it would guarantee "the full measure of individual rights and liberties" to the people by "sedulously maintain[ing] the strong arm of authority" (1913, 149-150). The modern-day historian Paul A. Kramer (2006Kramer, Paul A. 2006. The Blood of Government: Race, Empire, the United States, \& the Philippines. Chapel Hill, NC: University of North Carolina Press. [Google Scholar]) defines benevolent assimilation as bringing "metaphors of family, evolution, and tutelary assimilation into a gradualist, indeed indefinite, trajectory of Filipino 'progress' toward self-government" (161). Taking an oppositional stance to most contemporaneous observers of the US's consolidation of colonial power in the Philippines, Mark Twain wrote: "Benevolent Assimilation [ ... ] is the pious new name of the musket" (quoted in Zinn 2001Zinn, Howard. 2001. A People's History of the United States: 1492-Present. New York: Harper Collins. Amazon Kindle e-book. [Google Scholar], loc. 5929).

As is apparent from these quotations, glaring contradictions were inherent in the programme from its inception: political power-sharing with the Filipinos versus top-down control of them; free market economic modernization versus the prolongation of the Spanish-imposed semi-feudal mode of agricultural production; a widely publicized aspiration towards Philippine independence versus the US desire to retain the territory as a subordinate protectorate.

American novelists and travel writers of the period address these contradictions using various formal devices. In his gazetteer-cumtravelogue, United States Colonies and Dependencies Illustrated, William D. Boyce's (1914Boyce, William D. 1914. United States Colonies and Dependencies Illustrated. New York: Rand McNally. [Google Scholar]) dedication to the necessity of the American civilizing mission is evident from his surfeit of modalizing adjectives, intensifiers and exclamation marks. There is, he gushes, a "really wonderful prison system" (244) and "A good many Government officials live [in the Calle Escolta district], and army folks!" (224). Be that as it may, the almost histrionic tenor of Boyce's linguistic flourishes could be a form of unintended apophasis - most famously illustrated by Shakespeare's (1999Shakespeare, William. 1999. "Hamlet." In The Complete 
Works of William Shakespeare. Vol. 3. Ware: Wordsworth Editions. [Google Scholar]) telling line from Hamlet: "The lady doth protest too much, methinks" (3.2. 244) - whereby a speaker tries so assiduously to persuade the listener of a particular case of affairs that the listener begins to distrust the reliability of the claim. If Queen Gertrude doubts the sincerity of the actress character in Hamlet's play-within-a-play because she uses flowery and extravagant language, we might respond to Boyce's text in the same way, given that he refers to tension and unease within US officialdom about the efficacy of benevolent assimilation: "The appointment of Mr. [Francis Burton] Harrison [as Governor-General of the Philippines]", he writes, "has been to the detriment of our own just claims and anything but beneficial to the people of the Islands" (Boyce 1914Boyce, William D. 1914. United States Colonies and Dependencies Illustrated. New York: Rand McNally. [Google Scholar], xi).

Such modalities are as dubious as Boyce's easily verifiable excisions concerning the question of the new colonial order's moral authority. His belief that the unique experience of Americans having previously had "every square foot" of their country dominated by foreign states has taught them to treat their own, present-day overseas possessions more altruistically and inclusively, as "self-governing units of our great self-governing nation"

(Boyce 1914Boyce, William D. 1914. United States Colonies and Dependencies Illustrated. New York: Rand McNally. [Google Scholar], xi), is countered by Ashcroft, Griffiths, and Tiffin's (1998Ashcroft, Bill, Gareth Griffiths, and Helen Tiffin. 1998. Key Concepts in Post-Colonial Studies. London: Routledge. [Google Scholar]) assertion that, while "new" imperial doctrines such as benevolent assimilation projected a rhetorical "smokescreen of civilizing 'task' and paternalistic 'development' and 'aid' ", the material reality underneath involved the same old "violent and unjust [colonial] processes" (47). Furthermore, Boyce's sympathetic quoting of President McKinley - "We are to take to [ ... ] the Philippines the principles of liberty, of freedom of conscience, and of opportunity that are enjoyed by the people of the United States" (quoted in Boyce 1914Boyce, William D. 1914. United States Colonies and Dependencies Illustrated. New York: Rand McNally. [Google Scholar], 238) - is greatly at odds with Kramer's (2006Kramer, Paul A. 2006. The Blood of Government: Race, Empire, the United States, \& the Philippines. Chapel Hill, NC: University of North Carolina Press. [Google Scholar]) finding that Filipinos at that time did not in fact enjoy the same rights as their American counterparts; they had no guarantee of a jury trial and were not permitted to bear arms, for example (165). Equally as tendentious is Boyce's (1914Boyce, William D. 1914. United States Colonies and Dependencies Illustrated. New York: Rand McNally. [Google Scholar]) assumption that Filipinos are at liberty to "criticize the rule of the Americans or talk about Philippine independence by the hour" (240), which strikingly overlooks what was then the recent scandal over the Tagalog-language comic play Kapahon, Ngayon at Bukas (Yesterday, Today and Tomorrow). When the play premiered in 1903, a scene in which a character tramples upon a star- 
spangled banner was deemed seditious by the US authorities, who gaoled its author, Aurelio Tolentino, for nine years. A signatory to the Philippine Declaration of Independence in 1898 which was drawn up when there was still an understanding that the US would allow national self-determination, Tolentino had grown disillusioned with the corruption of the US Insular Government of the Philippine Islands and American perfidy on the independence issue (Kramer 2006Kramer, Paul A. 2006. The Blood of Government: Race, Empire, the United States, \& the Philippines. Chapel Hill, NC: University of North Carolina Press. [Google Scholar], 168).

Frank G. Carpenter's 1929Carpenter, Frank G. 1929. Through the Philippines and Hawaii. New York: Doubleday, Doran and Company. [Google

Scholar] travelogue Through the Philippines and Hawaii indirectly cautions against Philippine nationalism by recourse to the type of false objectivity we have seen in Stratemeyer's work. Carpenter's (1929Carpenter, Frank G. 1929. Through the Philippines and Hawaii. New York: Doubleday, Doran and Company. [Google Scholar]) plea for his personal neutrality - "I have preferred to tell what I have seen, letting my readers judge of conditions for themselves" (265) - is a conceit to assure the reader that his observations thereafter will be received as fair, balanced and commonsensical. However, Carpenter goes on to present a highly selective analect of viewpoints "expressed by men I have met in my travels who seem to me to be qualified to speak with authority on the subject [of the future of Philippine politics]" (265), all of whom just so happen to endorse the US's continued presence in the archipelago. "Possession of the Philippines is a vital necessity to the defence of the United States", one unnamed army officer tells him (267). An American academic, also anonymous, "contends that if independence should be granted, the Christian Filipinos are sure to set up a despotic rule" (269). Carpenter's narrowing of the frame of the debate, which, as the media linguist Roger Fowler (1991Fowler, Roger. 1991. Language in the News: Discourse and Ideology in the Press. Oxford: Routledge. [Google Scholar]) would put it, conveys "a partial view of the world" (11), might have been motivated by either "[unconscious] ideas and beliefs" (3) or a conscious intention to parrot hegemonic political attitudes. If the latter is the case, Carpenter's entreaty about his own disinterest in the topic is arguably another instance of inadvertent apophasis.

\section{Gendered assimilation}

Many of the writers discussed in this article mobilize gender-related metaphors in their depictions and discussions of benevolent assimilation. Jack Curzon's eponymous protagonist, a British clerk based in Singapore, is motivated to travel to the Philippines by his love for Mazie Gordon, whose beautiful, mixed American Filipina looks have "captured the [hearts of the] United States Navy" (Gunter 1898Gunter, Archibald Clavering. 1898. Jack Curzon (Being a Portion of the Records of the Managing Clerk of Martin, 
Thompson \& Co., English Merchants Doing Business in Hong Kong, Manila, Cebu and the Straits Settlements). Hurst: New York. [Google Scholar], 17). As the narrative unfolds, Curzon's quest to win Mazie's heart runs parallel with the US's deepening involvement in the revolutionary turmoil in Manila. In the dénouement of the novel, as the happy couple Curzon and Mazie are preparing to ride away in a carriage to a new life together, an Irish American soldier asks: "Why are thase beauteous brides loike thase same blessed Dewey Islands? [sic]" (330). To which his senior officer replies: "Because they'll be almighty ticklish critters to handle." Mazie laughs at this, and the Irish American further compares Filipino women with American imperial ambitions by stating that "the Germans wanted 'em and couldn't get 'em!" After more laughter symbolizing concord between these characters - and the cultures and colonial-political interests they represent - Curzon "step[s] into [his] carriage where a little fluttering beauty gathers in her gauzes to make room for Señor Jack Curzon" (330). The scene would appear to reify Vernadette Vicuña Gonzalez's (2013Gonzalez, Vernadette Vicuña. 2013. Securing Paradise: Tourism and Militarism in Hawai'i and the Philippines. Durham, NC: Duke University Press.[Crossref], [Google Scholar]) proposition that America's domination of the Philippines has historically been propelled by a male imperial fantasy of "securing" a feminized, submissive periphery "receptive to and in need of being claimed" (12), vindicated by "deeply felt understandings of American rescue", "liberation, "benevolence", "love" and "allegiance" (3). For Gonzalez, the fantasy has been sustained up to the present day not least because Filipino women themselves, from sex workers to domestic labourers, have internalized it, though not without having been pressured to do so by myriad social, political and economic factors. Thus, Mazie's love for Curzon against all the odds, and her approving laughter at the overt analogies between native women and the geopolitical designs of the American Empire, can be seen as prototypical of the phenomenon Gonzalez identifies.

\section{Parataxis and the city}

Charles King's (1901King, Charles. 1901. Ray's Daughter: A Story of Manila. Philadelphia, PA: Lippincott. [Google Scholar]) novel Ray's Daughter: A Story of Manila imagines benevolent assimilation in spatial and geographic terms. King shows that the Americans will correct or at least improve Manila's status as a colonial city planned by the Spanish to segregate communities of natives from zones inhabited by the expatriate ruling class, or "worlds cut in two", as Frantz Fanon (1990Fanon, Frantz. 1990. The Wretched of the Earth. London: Penguin. [Google Scholar]) has observed of comparable colonial milieux, between the "settler" and the "Negro" (or indigenous equivalent) towns (38). In King's starry-eyed vision, US sailors roam freely between the social, racial and cultural frontiers that the "antiquated" Spanish had erected to divide and rule Manileños for centuries: 
All over the massive, antiquated fortifications of old Manila into the tortuous mazes of the northern districts through the crowded Chinese quarter, foul and ill savored, the teeming suburbs of the native Tagals, humble yet cleanly; along the broad, shaded avenues, bordered by stately old Spanish mansions, many of them still occupied by their Castilian owners, the Yankee invaders wandered at will. (King 1901King, Charles. 1901. Ray's Daughter: A Story of Manila. Philadelphia, PA: Lippincott. [Google Scholar], 173)

King hints that Manila's heterogeneous populace will be unified by these sailors - and the colonial functionaries who will come after them - under a new cohesive identity defined by liberty, democracy and equality. Painting the American arrival in idyllic terms, he gleefully declares that the "Yankee invaders" are "brimful of curiosity and good nature [ ... ] making themselves perfectly at home, filling $[\ldots$ ] the natives with wonderment through their lavish, jovial and free and easy ways" (King 1901King, Charles. 1901. Ray's Daughter: A Story of Manila. Philadelphia, PA: Lippincott. [Google Scholar], 174). (The phrase "making themselves perfectly at home" is an intriguing choice given its relational function to the word "assimilation".) For King, benevolent assimilation is in the interests of both colonized and colonizer; the sailors who quickly get to know the city as well as "the streets of their own home villages" (174) are assimilating into Manila life while Manileños appear happy to assimilate into the American Way. However, with the benefit of historiographical hindsight, King's prescription seems impractical and idealistic even by the standards of gung-ho, jingoistic colonial fiction, given the modern historian Carl H. Nightingale's (2012Nightingale, Carl H. 2012. Segregation: $A$ Global History of Divided Cities. Chicago: University of Chicago

Press.[Crossref], [Google Scholar]) claim that the US colonial state did little to rectify Spanish segregationism, instead extending and multiplying Manila's socio-geographical inequalities by converting the Escolta neighbourhood into a "kind of American zone" and constructing the whites-only hill station of Baguio (301). Moreover - to analyse King's rendering of Manila from a slightly different perspective - he reinforces the city's spatial hierarchy of classes and ethnic groups (the Chinese quarter, the Tagalog suburbs and so forth) in a manner not unlike Gunter's delineation of a clear socio-geographical pecking order in Jack Curzon: "More aristocratic San Miguel, the busy hives of enterprising foreign merchants, ingenuous Tagal artisans, crafty Chinese traders, and tireless sweating coolies" (Gunter 1898Gunter, Archibald Clavering. 1898. Jack Curzon (Being a Portion of the Records of the Managing Clerk of Martin, Thompson \& Co., English Merchants Doing Business in Hong Kong, Manila, Cebu and the Straits

Settlements). Hurst: New York. [Google Scholar], 66). Gunter mentions the well-heeled suburbs and financial centre first, followed by Malay Filipino and Chinese Filipino professionals, and, at the foot of the ranks, the coolie menial labourers. However, he implies a certain equality - or at least commonality of purpose - between these subcultures when he lauds their contribution to "the modern Manila, that commercial emporium, which ships the immense produce 
of these islands to the utmost ends of the earth" (66). Both his and King's instances of "parataxis", defined by Spurr (1993Spurr, David. 1993. Rhetoric of Empire: Colonial Discourse in Journalism, Travel Writing and Imperial Administration. Durham, NC: Duke University Press. [Google Scholar]) as the tendency of the orientalist gaze to place "things side by side" (17) in a hierarchy of value judgements, mirror one of the prime paradoxes of the American project in Manila: on the one hand, in order to cement its control the new colonial order needed to preserve three centuries-old power structures (often manifested in urban geographical divisions), while on the other, it was eager from the outset to present itself as a more progressive administration that encouraged the social integration of Filipinos and their consent in their own governance.

\section{Conclusion}

As we saw in the earlier parts of this article, the long-standing discursive blackout of the Philippine-American War started while the conflict was still going on, with the sentiments of most popular fiction, memoir, travel writing and journalism coterminous with the US military's attitude that the violent "chastisement" of the archipelago "was something best kept out of the public eye" (Rockoff 2012Rockoff, Hugh. 2012. America's Economic Way of War: War and the US Economy from the Spanish-American War to the Persian Gulf War. New York: Cambridge University Press.[Crossref], [Google Scholar], 78). However, there was no shortage of contemporaneous resistance to the conflict within the US political and business establishments; industrialist Andrew Carnegie, former US President Grover Cleveland and three-time Democrat Party presidential candidate William Jennings Bryan were all strongly opposed to America's new imperialistic agenda. It logically follows, then, that some mainstream journalists of the period were prepared to disclose the true horrors of the Philippine battlefield. "Our men have been relentless", wrote the Philadelphia Ledger's Asian correspondent in November 1901, and "have killed to exterminate men, women, children, prisoners and captives, active insurgents and suspected people from lads of ten up, the idea prevailing that the Filipino as such was little better than a dog" (quoted in Zinn 2001Zinn, Howard. 2001. A People's History of the United States: 1492Present. New York: Harper Collins. Amazon Kindle e-book. [Google Scholar], loc. 3445). Perhaps the most famous American writer of the turn of the 20th century, Mark Twain, published caustic lampoons of the problematic fusion of religion, patriotism and militarism propelling the US and other western empires:

I bring you the stately matron named Christendom, returning bedraggled, besmirched, and dishonored, from pirate raids in Kiaochow, Manchuria, South Africa, and the Philippines, with her soul full of meanness, her pocket full of boodle, and her mouth full of pious hypocrisies. Give her soap and towel, but hide the looking glass. $(1900,2)$ 
Valiant as they were, contrary voices such as Twain's were sidelined and, in the clamour to capture the hearts and minds of the American public, were drowned out by the high-circulation, often feverishly hawkish "yellow" newspapers owned by Joseph Pulitzer and William Randolph Hearst, not to say the simplistic and tendentious - and widely read - fictions I have analysed above. Perhaps more importantly, though, the complaints of even influential figures such as Carnegie and Bryan were never likely to be heeded by the majority of politicians, tycoons, civil servants and diplomats, given the strategic and economic rewards offered by empire-building. As Theodore Roosevelt put it in 1899, "The master of Manila can make terms with every power in the East, and those vast markets must be held open in the interest of our industry and our commerce" (quoted in

Rockoff 2012Rockoff, Hugh. 2012. America's Economic Way of War: War and the US Economy from the Spanish-American War to the Persian Gulf War. New York: Cambridge University Press.[Crossref], [Google Scholar], 70). Through the manipulative and propagandistic employment of rhetorical conceits, Stratemeyer, King, Gunter and other authors were able to provide an ideological vindication for the manoeurres by which the US became "master of Manila". Like minds, working in fiction, print journalism, radio, television, film and the Internet have been doing much the same ever since. The current generation of "liberal interventionists" espouses an updated formulation of benevolent assimilation that substitutes the idioms of paternalism, cultural improvement and mutually beneficial dependency with the vocabulary of secularism, international law, "liberal democratic governance" and economic "growth" (Bosco 2012Bosco, David. 2012. "What Divides Neocons and Liberal Interventionists." Foreign

Policy, April 9.https://foreignpolicy.com/2012/04/09/what-divides-neocons-andliberal-interventionists/ [Google Scholar]). In both the old and new conceptions of benevolent assimilation, a good deal of discursive legerdemain is required to conceal or distract from the murder, destruction, torture and displacement that are direct consequences of martial adventurism.

Moreover, the gendered aspects of benevolent assimilation alluded to earlier have become more pronounced in the present era. In addition to dramatizing Mazie's symbolic embrace of American values through romance and marriage, Jack Curzon frequently mentions the social advantages enjoyed by American women, including limited suffrage, the right to stand for mayoral election (Gunter 1898Gunter, Archibald Clavering. 1898. Jack Curzon (Being a Portion of the Records of the Managing Clerk of Martin, Thompson \& Co., English Merchants Doing Business in Hong Kong, Manila, Cebu and the Straits Settlements). Hurst: New York. [Google Scholar], 29) and the freedom to indulge "the cigarette habit" (85) - this despite the novel's twin masculinist narratives concerning the conquest of both the Philippines and a Filipina. Arguably, these vague articulations precede the contemporary discourses of western non-governmental organizations (NGOs), charities, women's magazines and reality television shows that, according to Mimi Thi Nguyen 
(2010), "represent women in the global South as needing modernization" (374) in relation to a paradigm that "constructs Western women as ethical and free" as opposed to their counterparts in "patriarchal states or 'backward' cultures" (371).

Finally, I intend this article as a useful addition to the somewhat limited repertory of research into American orientalist idées fixes about Asia, especially given that the exercise of American military, diplomatic, economic and cultural power continues apace, and better comprehension of the origins of its self-justificatory logic is useful for several reasons. As the Filipino historiographer Oscar V. Campomanes (1999Campomanes, Oscar V. 1999. "1898 and the Nature of the New Empire." Radical History Review 73: 130146. doi:10.1215/01636545-1999-73-130.[Crossref], [Google Scholar]) suggests, close interrogation of period literature that articulates "the history of 1898" (131) can help scholars to answer "the question of what to teach" (132) today and therefore, presumably, boost public awareness of this hitherto under-reported conflict. Furthermore, it can contribute to definitions of the American Empire's "nature", "temporality or duration" and "its peculiar forms or formulations of territoriality"; all of which contribute to holding "U.S. global power [ ... ] critically accountable" (132). That accountability is paramount, given the sheer extent of that power today - whether we quantify it in terms of the US's current involvement in over 100 wars worldwide or its battle-ready troop presence in 172 countries (Editorial Board 2017, 1) - which the likes of McKinley and his literary allies would never have anticipated.

\section{Disclosure statement}

No potential conflict of interest was reported by the author.

\section{References}

1. Ashcroft, Bill, Gareth Griffiths, and Helen Tiffin. 1998. Key Concepts in Post-Colonial Studies. London: Routledge.

[Google Scholar]

Open URL

2. Blanton, Casey. 2002. Travel Writing: The Self and the World. New York: Routledge. 
3. Bosco, David. 2012. "What Divides Neocons and Liberal Interventionists." Foreign Policy, April 9.https://foreignpolicy.com/2012/04/09/what-divides-neocons-andliberal-interventionists/

\section{[Google Scholar]}

\section{Open URL}

4. Boyce, William D. 1914. United States Colonies and Dependencies Illustrated. New York: Rand McNally.

\section{[Google Scholar]}

\section{Open URL}

5. Bush, George. 2003. We Will Prevail: President George W. Bush on War, Terrorism and Freedom. New York:Continuum.

\section{[Google Scholar]}

\section{Open URL}

6. Campomanes, Oscar V. 1999. "1898 and the Nature of the New Empire." Radical History Review 73: 130-146. doi:10.1215/01636545-1999-73-130.

\section{[Crossref]}

\section{[Google Scholar]}

\section{Open URL}

7. Carpenter, Frank G. 1929. Through the Philippines and Hawaii. New York: Doubleday, Doran and Company.

\section{[Google Scholar]}


8. Constantino, Renato. 2010. A History of the Philippines: From Spanish Colonization to the Second World War.New York: Monthly Review Press.

[Google Scholar]

Open URL

9. Fairclough, Norman. 2013. Language and Power. Oxford: Routledge.

[Google Scholar]

Open URL

10. Fanon, Frantz. 1990. The Wretched of the Earth. London: Penguin.

[Google Scholar]

Open URL

11. Ferguson, Niall. 2009. Colossus: The Rise and Fall of the American Empire. London: Penguin.

[Google Scholar]

Open URL

12. Fowler, Roger. 1991. Language in the News: Discourse and ldeology in the Press. Oxford: Routledge.

\section{[Google Scholar]}

\section{Open URL}

13. Freud, Sigmund. 2001. Totem and Taboo. Oxford: Routledge.

[Google Scholar] 
14. Gonzalez, Vernadette Vicuña. 2013. Securing Paradise: Tourism and Militarism in Hawai'i and the Philippines.Durham, NC: Duke University Press.

\section{[Crossref]}

\section{[Google Scholar]}

\section{Open URL}

15. Gunter, Archibald Clavering. 1898. Jack Curzon (Being a Portion of the Records of the Managing Clerk of Martin, Thompson \& Co., English Merchants Doing Business in Hong Kong, Manila, Cebu and the Straits Settlements).Hurst: New York.

\section{[Google Scholar]}

\section{Open URL}

16. Holland, Patrick, and Graham Huggan. 2000. Tourists with Typewriters: Critical Reflections on Contemporary Travel Writing. Ann Arbor, MI: University of Michigan Press.

\section{[Google Scholar]}

\section{Open URL}

17. Ileto, Reynaldo C. 2002. "The Philippine-American War: Friendship and Forgetting." In Vestiges of War: The Philippine-American War and the Aftermath of an Imperial Dream 1899-1999, edited by Angel Velasco Shaw andLuis H Francia, 3-21. New York: New York University Press.

\section{[Google Scholar]}

\section{Open URL}

18. lleto, Reynaldo C. 2017. Knowledge and Pacification: On the U.S. Conquest and the Writing of Philippine History.Manila: Ateneo de Manila University Press. 


\section{[Google Scholar]}

\section{Open URL}

19. Johnson, Lyndon. 1965. "Why We Are in Vietnam." In Modern America: A Documentary History of the Nation since 1945, edited by Gary Donaldson, 117120. New York: Routledge.

\section{[Google Scholar]}

\section{Open URL}

20. King, Charles. 1901. Ray's Daughter: A Story of Manila. Philadelphia, PA: Lippincott.

\section{[Google Scholar]}

\section{Open URL}

21. Kramer, Paul A. 2006. The Blood of Government: Race, Empire, the United States, \& the Philippines. Chapel Hill, NC: University of North Carolina Press.

\section{[Google Scholar]}

\section{Open URL}

22. McKinley, William. 1898. "War Message." In Papers Relating to Foreign Affairs, editor unnamed, 750-760.Washington, DC: US Department of State.

\section{[Google Scholar]}

\section{Open URL}

23. McKinley, William. 2011. "William McKinley: Benevolent Assimilation." Letter, December 21st 1898." In The Encyclopedia of the Spanish-American and PhilippineAmerican Wars Vol. 1, edited by Spencer C Tucker, 924.Santa Barbara, CA: ABC Clio.

\section{[Google Scholar]}


24. Monbiot, George. 2004. "Empire of Denial." The

Guardian, June 1.https://www.theguardian.com/world/2004/jun/01/usa.comment

\section{[Google Scholar]}

\section{Open URL}

25. Netzorg, Walton J. 1990. "The Philippines in Mass-Market Novels." In Asia in Western Fiction, edited by Robin WWinks and James R Rush, 175195. Manchester: Manchester University Press.

\section{[Google Scholar]}

\section{Open URL}

26. Nguyen, Mimi Thi. 2011. "The Biopower of Beauty: Humanitarian Imperialisms and Global Feminisms in an Age of Terror." Signs: Journal of Women in Culture and Society 36 (2): 359-383. doi:10.1086/655914.

[Crossref], [PubMed], [Web of Science @]

\section{[Google Scholar]}

\section{Open URL}

27. Nightingale, Carl H. 2012. Segregation: A Global History of Divided

Cities. Chicago: University of Chicago Press.

[Crossref]

\section{[Google Scholar]}

\section{Open URL}

28. Obama, Barack. 2011. "Remarks by the President in Address to the Nation on Libya."https://obamawhitehouse.archives.gov/the-press-office/2011/03/28/remarkspresident-address-nation-libya 
[Google Scholar]

\section{Open URL}

29. Peace, Roger. 2010. "Cultivating Critical Thinking: Five Methods for Teaching the History of U.S. Foreign Policy." The History Teacher 43: 265-273.

\section{[Google Scholar]}

\section{Open URL}

30. Pullum, Geoffrey K. 2014. "Fear and Loathing of the English Passive." Language and Communication 37 (2): 1-6. doi:10.1016/j.langcom.2013.08.009.

\section{[Crossref]}

\section{[Google Scholar]}

\section{Open URL}

31. Rockoff, Hugh. 2012. America's Economic Way of War: War and the US Economy from the Spanish-American War to the Persian Gulf War. New York: Cambridge University Press.

\section{[Crossref]}

\section{[Google Scholar]}

\section{Open URL}

32. Rodriguez, Dylan. 2010. Suspended Apocalypse: White Supremacy, Genocide, and the Filipino Condition.Minneapolis, MN: University of Minnesota Press.

\section{[Google Scholar]}

\section{Open URL}

33. Roosevelt, Theodore. 1904. "Special Message, January 4." In The American Presidency Project, edited by GerhardPeters and John T Woolley, http://www.presidency.ucsb.edu/ws/?pid=69417 


\section{[Google Scholar]}

\section{Open URL}

34. Said, Edward. 1985. Orientalism. London: Peregrine.

\section{[Google Scholar]}

\section{Open URL}

35. Scheffer, David J. 1992. "Towards a Modern Doctrine of Humanitarian Intervention." University of Toledo Law Review 23: 253-274.

[Google Scholar]

\section{Open URL}

36. Shakespeare, William. 1999. "Hamlet." In The Complete Works of William Shakespeare. Vol. 3. Ware: Wordsworth Editions.

\section{[Google Scholar]}

\section{Open URL}

37. Spurr, David. 1993. Rhetoric of Empire: Colonial Discourse in Journalism, Travel Writing and Imperial Administration. Durham, NC: Duke University Press.

\section{[Google Scholar]}

\section{Open URL}

38. Stratemeyer, Edward. 1898. Under Dewey at Manila or the War Fortunes of a Castaway. Boston, MA: Lee and Shepard.

\section{[Google Scholar]}


39. Stratemeyer, Edward. 1900. The Campaign of the Jungle or under Lawton through Luzon. Boston, MA: Lee and Shepard.

\section{[Google Scholar]}

\section{Open URL}

40. Stratemeyer, Edward. 1902. Under MacArthur in Luzon or Last Battles in the Philippines. Boston, MA: Lee and Shepard.

\section{[Google Scholar]}

\section{Open URL}

41. Tadiar, Neferti, and M. Xina. 2004. Fantasy-Production: Sexual Economies and Other Philippine Consequences for the New World Order. Hong Kong: Hong Kong University Press.

\section{[Google Scholar]}

\section{Open URL}

42. The Editorial Board. 2017. "America's Forever Wars." New York Times. October 22.https://www.nytimes.com/2017/10/22/opinion/americas-foreverwars.html

\section{[Google Scholar]}

\section{Open URL}

43. Twain, Mark. 1900. "A Salutation to the Twentieth Century." In The New York Herald, December 30.

[Google Scholar]

\section{Open URL}

44. Young, Robert J.C. 1995. Colonial Desire: Hybridity in Theory, Culture and Race. London: Routledge. 


\section{[Google Scholar]}

\section{Open URL}

45.Zinn, Howard. 2001. A People's History of the United States: 1492-Present. New York: Harper Collins. Amazon Kindle e-book.

[Google Scholar]

Open URL

\section{Additional information}

\section{Author information}

\section{Tom Sykes}

Tom Sykes is senior lecturer in creative writing at the University of Portsmouth. His articles have appeared in A Global History of Literature and the Environment (2017) and in Social Identities, Foundation and Children's Literature Review. He is currently preparing A Cultural History of Manila for I.B. Tauris. His latest book is a "political travelogue" entitled The Realm of the Punisher: Travels in Duterte's Philippines (2018). 